\title{
VI
}

\section{Dostoevsky and Nietzsche: The Hazards of Writing Oneself into (or out of) Belief}

David S. Cunningham*

For many years I taught an undergraduate course called Atheists and Apologists, usually as an upper-level seminar in a Religious Studies department. Students were assigned ten primary texts-actually, five pairs of texts, each of which brought two approximately contemporaneous figures into conversation with one another. The paired writers were chosen because they displayed quite significantly different views about God, faith, and morality. Nevertheless, in constructing the pairings, I always tried to complicate any easy conclusions about precisely what makes a particular author an "atheist" and what makes another an "apologist" for religious belief. So, for example, the classes were asked to read Descartes in tandem with Pascal; both authors profess to be believers, but students quickly recognize that they offer very different accounts of belief. In fact, Descartes's rationalism can quickly seem to eclipse his profession of faith. Similarly, many students find Hegel's supposed Christian faith to be distant and sterile, whereas Marx's apparently atheistic arguments are filled with theologically charged turns of phrase.

My thanks are due to Svetlana Evdokimova at Brown University for inviting me to the conference on Dostoevsky, where I presented this material in a (much) earlier form. In particular, I am grateful for her hospitality at the conference and for her patience as the revision of this chapter lingered far too long. Thanks also to Rowan Williams, my theological teacher and mentor. 
One of our five pairs of authors - indeed, one of the few that I never altered in some twelve iterations of the course-was Nietzsche and Dostoevsky. We would usually read excerpts from The Gay Science and Zarathustra, and the whole of The Antichrist; this was followed by reading The Brothers Karamazov in its entirety.

Both authors challenge my classroom participants on a variety of levels. In Dostoevsky's portrayal of Alyosha, the students know they have found a believer, but they don't always find him sympathetic; they also find "Rebellion" and "The Grand Inquisitor" to be among the strongest arguments against faith, and particularly against the Christian faith in its modern form, that they have ever encountered. Similarly, they feel somewhat bludgeoned by Nietzsche's flaming atheistic tirades, particularly in The Antichrist; yet they are also puzzled by his apparent inability to let go of God, even as he rails against the very idea. In Dostoevsky, they discover a Christian who has constructed the strongest possible case for atheism; in Nietzsche, they find an atheist who can't get God off his mind.

The students read primary texts exclusively; I offer them very little in the way of historical background. As a result, most of the students are, somewhat accidentally, readers who both affirm and exemplify the literary-theoretical position identified as "the death of the author." They cannot fall into the "intentional fallacy," because they know far too little about either of these men or their intentions. They have to rely almost exclusively on the texts themselves in order to glean any sense of what either author believed. I provide only the scantiest biographical details, and few students bother to learn more about either man on their own. Thus, as indicators of the impact of each author's writing (without reference to his actual intentions and beliefs), the students provide me with a relatively unalloyed reading; they therefore make useful test cases for how one might discern each author's attitude toward religious faith, using only his published texts as a guide.

Mostly, the students find the texts confusing. One student might experience his faith being sorely tested by Ivan's account of cruelty to children, while another finds Zosima enlightening; one quotes a typical insult from The Antichrist, while another observes that, as far as she can tell, only the madman seems to understand the earth-shattering impact of the murder of God. My undergraduates are not particularly skilled readers, but I think their instincts are 
sound-particularly when they express some uncertainty about where both authors stand. Partly as a result of this lack of clarity, most of them don't find either author particularly convincing (though for different reasons). In the case of Dostoevsky, they don't know what he really believes: he seems to argue both for and against belief. In Nietzsche's case, they can't really miss the fact that he thinks belief is a bad idea, but his tirades don't seem to move them. In the latter case, the author fails to persuade; in the former case, the students can't usually decide what it is, exactly, of which the author is trying to persuade them. It is the difference between these two perspectives that interests me most, and to which I will return shortly.

\section{Writing to Believe (or to Deny Belief)}

It is something of a commonplace to describe both Nietzsche and Dostoevsky as thinkers who employed their skills as writers to provide themselves with an opportunity to work through their views about faith. In both cases, their writing is laced with theological terminology and biblical allusionsthey write about God and about the gods, about demons and angels, about characters who are obsessed with theological or atheological claims. At the risk of oversimplifying, we can observe that Nietzsche was constantly trying to write himself out of the faith into which he, as the son of a Protestant pastor, had been born; Dostoevsky, on the other hand, was trying to write himself back into the faith from which he had become estranged through various political and philosophical experiments. For Dostoevsky and for Nietzsche, the act of writing is a means by which each man tries to make sense of a faith that is in dynamic motion - a faith that is in the process either of dying or of rising again. That Dostoevsky is wrestling with the call of Christ is attested by his seemingly contradictory assertions of unquenchable doubt and unshakable belief. Nietzsche, born into faith and aware of its powers of temptation, is eager to prove to himself that he has rid himself of it. Yet he continues to feel the need to make this case, in practically everything he writes-until, finally, he is able to write no more.

The two authors were thus engaged in a very similar enterprise, even if they were moving in opposite directions. As Janko Lavrin put the matter, many decades ago, 
In his passionate wish for religion Dostoevsky had to explore the problem of God from the angle of a believer and an unbeliever. Yet in contrast to the pious young Nietzsche (who, despite his subsequent denial of everything religious and Christian, at first studied theology at Bonn University in order to become a pastor), Dostoevsky's youth was marked by skepticism which tormented him to the end of his life. ${ }^{1}$

The skepticism that Lavrin mentions here, and that haunted Dostoevsky so profoundly, is both well known and well documented-in everything from his political activities to his personal reflections. In a much-cited letter of 1854, Dostoevsky wrote,

I can tell you about myself that I am a child of this century, a child of doubt and disbelief, I have always been and shall ever be (that I know), until they close the lid of my coffin. What terrible torment this thirst to believe has cost me and is still costing me, and the stronger it becomes in my soul, the stronger are the arguments against it. ${ }^{2}$

This skepticism, however, is deeply complicated by a later passage in the same letter-a passage that seems, to many readers, to suggest quite the opposite of skepticism, a kind of obscurantism or fideism:

If someone were to prove to me that Christ was outside the truth, and it was really the case that the truth lay outside Christ, then I should choose to stay with Christ rather than with the truth. ${ }^{3}$

Everyone who reads these words - from deeply invested scholars to very occasional readers - tends to come away from them with profound uncertainties about Dostoevsky's faith. In contrast, very few readers have expressed much hesitation in summarizing Nietzsche's position: he is simply an atheist. He may employ a great deal of theological language in his writing, but there seems to be very little question about where he himself stands.

1 Janko Lavrin, “A Note on Nietzsche and Dostoevsky," Russian Review 28, no. 2 (1969): 163.

2 Letters of Fyodor Michailovitch Dostoevsky to His Family and Friends, trans. Colburn Mayne (Chatto and Windus, 1914); cited in Lavrin, "A Note," 164.

3 This translation is from Malcolm Jones, "Dostoevskii and Religion," in The Cambridge Companion to Dostoevskii, ed. W. J. Leatherbarrow (Cambridge: Cambridge University Press, 2002), 155-56. 
The passages in Dostoevsky's letter (as quoted above) have been subjected to a great deal of critical scrutiny, and have been interpreted in multiple ways. One of the clearest accounts of what they might mean, and of how we might better understand Dostoevsky's faith through them, comes from the pen of Rowan Williams:

\begin{abstract}
Dostoevsky's confession of 1854, whatever exactly it meant to him at the time of writing, comes to mean something like this. "Truth," as the ensemble of sustainable propositions about the world, does not compel adherence to any one policy of living rather than another; if faith's claims about Christ do not stand within that ensemble of propositions, that is not a problem. It means that they cannot be confused with any worldly power that might assume the right to dictate a policy for living or impose a reconciliation upon unwilling humanity. This does not mean that they are irrational in the sense of contradictory or in the sense of being arbitrarily willed; they represent something that can make possible new notions of moral awareness precisely because they are not generated by the will.... At this level, response to Christ connects with a "truth" that is more comprehensive than any given ensemble of facts. ${ }^{4}$
\end{abstract}

Needless to say, this is a complicated position for Dostoevsky to take. But even if it accurately reflects his views (or, at any rate, his views in 1854), can the same views be gleaned simply by reading his published writings? Would readers come to the same conclusion that Williams reaches here, if they had only read Dostoevsky's novels?

My own consideration of this question has led me to argue that, in using one's published writing as a means of wrestling with (and therefore communicating about) one's faith, one undertakes - as my title suggests - a very hazardous practice. This is particularly the case if one hopes to be understood, to communicate one's views to others. At the end of this chapter, I will return to the question of whether the hazardous nature of this enterprise might have more to do with the content of the writing-the question of faith - than it does with one's particular method of writing about it. In the meantime, it is precisely the different methods that Dostoevsky and Nietzsche employ which interests me, because it suggests that the hazards involved in their efforts to write about their faith are hazardous in different ways. To that difference I now return.

4 Rowan Williams, Dostoevsky: Language, Faith, and Fiction (Waco, TX: Baylor University Press, 2008), 26. 


\section{The Difference (and Why It Makes a Difference)}

As I noted above, my students tend to be more confused by Dostoevsky, even though they are not particularly persuaded by Nietzsche. It may be, of course, that readers experience the attempt to generate faith through writing as simply more challenging and more complicated than is the attempt to eliminate it. Or, to say the same thing another way: writing one's way into faith may just be more interesting, and more fraught, than writing one's way out of it. Although I'm willing to consider this as a possible reason for the difference, it doesn't strike me as very likely, and I suspect that one could offer some interesting counterexamples in the work of other writers. In any case, I think there may be better explanations.

One such explanation has to do with genre. Dostoevsky wrote fiction, and even the nonfiction that he wrote has such a strong literary quality that many critics find themselves wondering just how fictional some of his letters and diaries may be. For Nietzsche, fiction was clearly not his primaryidiom. Admittedly, Zarathustra is something like a fable; in essence, however, it is-like many of Nietzsche's works - a set of aphorisms, collected into a loose narrative frame. As Nietzsche himself said, "Whoever writes in blood and aphorisms does not want to be read but to be learned by heart." ${ }^{5} \mathrm{He}$ tells us exactly what he thinks, and what we should think; as a result, his attitudes about God and belief lie somewhat nearer the surface. We can, of course, plumb Nietzsche's aphorisms for a certain kind of "movement" on questions of faith, some of which may lie fairly deeply buried; that, however, is a different kind of enterprise than the reading of a novel, in which multiple characters vie for our attention. In Dostoevsky's fiction, in particular, as Bakhtin famously noted,

a plurality of independent and unmerged voices and consciousnesses, a genuine polyphony of fully valid voices, is in fact the chief characteristic of Dostoevsky's novels. What unfolds in his works is not a multitude of characters and fates in a single objective world, illuminated by a single authorial consciousness; rather a plurality of consciousnesses, with equal rights and each with its own world, combine but are not merged in the unity of the event. ${ }^{6}$

5 Friedrich Nietzsche, Thus Spake Zarathustra, in The Portable Nietzsche, trans. and ed. Walter Kaufmann (New York: Viking, 1954), pt. 1, sec. 7 (“On Reading and Writing”), 152.

6 M. M. Bakhtin, Problems of Dostoevsky's Poetics, ed. and trans. Caryl Emerson, with an introduction by Wayne C. Booth (Minneapolis: University of Minnesota Press, 1984), 6. The entire opening part-sentence of this quotation is italicized in the original. 
These fully valid voices, distributed widely among the characters, make it very difficult indeed to "read off" the author's genuine beliefs from the actions and words on the page.

Still, we at least learn something about various authors' attitudes toward belief by their decisions to write in particular genres. Fiction, it has been argued, is one of the few forms of writing through which we may come to grasp one of the most defining facts about God - which is that God, by definition, cannot be grasped. Indeed, this is one of the factors that make fictional literature such an important vehicle for teaching about religious belief, and, in particular, about belief in God.' God's indefinability means that God cannot be spoken of in definitive language, but only in fits and starts-only in full recognition of the brokenness and ultimate impossibility of the enterprise.

In other words, the only way to write or speak about God, as Rowan Williams notes, is "to go on speaking [and] writing about God, allowing the language of faith to encounter fresh trials every day, and also fresh distortions and refusals." Williams observes that fiction may be the most appropriate mode for doing this, because at its best, it refuses to come to closure: "Every morally and religiously serious fiction has to project something beyond [its] ending or otherwise signal a level of incompletion, even in the most minimal and formal mode, indicating an as-yet-untold story." This helps us understand Williams's comment elsewhere that there can be no fundamentalist fiction $;^{10}$ if every detail about God is a fundamental truth in propositional form, then an author can never create the all-important lacunae and open structures that mark all great fiction.

In spite of all this, however, my student readers of Dostoevsky are rarely satisfied with the incompleteness and lack of closure that Williams here endorses. They are not comfortable dwelling in the kingdom of the open text and celebrating their accidental embrace of "the death of the author." They want to know where a writer stands on matters of faith, and, if possible, they want to

7 David S. Cunningham, Reading Is Believing: The Christian Faith through Literature and Film (Grand Rapids, MI: Brazos, 2004), 31-37.

8 Williams, Dostoevsky, 46.

9 Ibid.

10 Ibid., 60. Williams also makes similar points in a variety of other writings about the relationship of theology and literature. 
figure that out just by using the text that sits in front of them. ${ }^{11}$ On this score, Dostoevsky presents the students with a particular challenge-perhaps because, as noted above, he seems to make such strong arguments for various views and positions. They are looking for a functional response to their questions: Does he believe, or doesn't he? Unfortunately for them, however, fiction-and Dostoevsky's fiction in particular-does not provide that response. Williams again:

Faith and fiction are deeply related — not because faith is a variant of fiction in the trivial sense, but because both are gratuitous linguistic practices standing over against a functional scheme of things. The gratuity of faith arises from its character as response to the freedom of the creator as unexpectedly encountered in the fabric of the world. The gratuity of fiction arises from the conviction that no kind of truth can be told if we speak or act as if history is over, as if the description of what contingently is becomes the sole possible account of language. A fiction like Dostoevsky's which tries to show what faith might mean in practice is bound to be both inconclusive in all sorts of ways, and also something that aspires to a realism that is more than descriptive. ${ }^{12}$

Indeed, we may go further. There may actually be something about the process of writing fiction that somehow opens up the possibility of belief. In the process of writing fiction, writing about characters whose destinies one does not yet know, one opens up the possibility of the gratuitous reception of a faith that one cannot yet affirm. In "the world of mathematical closure," says Williams, "the future is clear and there are no significant decisions to be made. In the world of the novel, when all this has been said, everything is still to play for." ${ }^{13}$

In addition, I should here point out that I ask my students to read only one of Dostoevsky's works (at least within this particular course-and in my experience, few have encountered him elsewhere). This further reduces their vision of the relationship between the author's faith and his published writings—and on this point, the same would be true for their views about Nietzsche. Given that faith was, for both writers, a thing in motion—something that was in the process of

11 I did not usually include readings from Kierkegaard in the course, but his frequent use of pseudonyms would have added another layer of mystery (and, I suspect, frustration) to the students' efforts to discern the author's point of view.

12 Williams, Dostoevsky, 46.

13 Ibid., 58. 
developing or devolving, as the case might be-readers need to be willing to examine the whole of the corpus, rather than rely on the kind of snapshot that will come from too narrow a focus on one particular work or one particular period in the author's life. The fact that my students receive such a minimal picture of each author makes them interestingly innocent, not only of each author's biographical background, but also of his complex development over time.

This suggests that my students might well feel the weight of all of the aforementioned complexities yet more strongly were they to trace what René Girard calls Dostoevsky's "spiritual evolution"14 — starting from the early works, then moving through The Idiot and The Possessed, and thence to Brothers Karamazov. If "evolution" is the correct way to describe it, Dostoevsky's is a particularly lengthy one: decades elapse; thousands of pages are published; the author is sent to prison in Siberia and returns home again. A student who has only read one novel has very little chance to make a well-grounded argument on this subject, and, indeed, a great many professional critics find it difficult to summon the degree of patient attention that would be necessary to offer a thoroughgoing account of the entire evolutionary journey. As Girard puts it:

Certain critics of Dostoevsky have the tendency to hurry the rhythm of his spiritual evolution, whether because they desire superficially to "Christianize" his work or, to the contrary, because they desire to de-Christianize it for their own convenience. For Dostoevsky, writing is a means of knowing, an instrument of exploration; it is thus always beyond the author himself, ahead of his intelligence and his faith. ${ }^{15}$

I want to emphasize and highlight that last phrase, because I will return to it shortly: Dostoevsky's writing is, Girard says, "ahead of his faith."

In a way, this is simply to repeat the claims that I made above in conversation with Rowan Williams - that is, that it belongs to the nature of fiction to resist closure, to leave uncertainties hanging, to be constantly "on the move." And Girard clearly wants to make this point himself, because he follows his quoted observation with the remark that "to say this is to say again that Dostoevsky is essentially a novelist." ${ }^{16}$ But this point about the genre of Dostoevsky's

14 René Girard, Dostoevsky: Resurrection from the Underground, ed. and trans. with an introduction by James G. Williams (New York: Crossroad, 1997), 101.

15 Ibid.

16 Ibid. 
writing does not exhaust the potential meaning in Girard's metaphorical description of that writing as "always beyond the author" - that it lies "ahead of his intelligence and his faith." In particular, the spatial metaphor of writing that is "beyond" or "ahead of" its author may help us distinguish the different kinds of hazards that Dostoevsky and Nietzsche face as they try to communicate about the nature of belief. That difference may lie not simply in whether one is trying to generate it or trying to stamp it out, nor even in whether one is writing fiction or aphoristic injunctions. Instead, the difference may be in whether one's writing ventures out "ahead of" one's faith, as Girard describes Dostoevsky's, or whether one's writing lags "behind" one's faith. Girard does not mark this contrast explicitly, but in the present context it seems well worth drawing out.

By "those whose writing lags 'behind' their faith," I am referring to those who assume that they have made all the relevant decisions about faith securely, and that they are writing simply to express their already determined views. This path allows the author to settle the questions first-or at least to assume that they have been settled by others-and only then to write about them. This can be done either by believers or nonbelievers, and in a variety of genres. A believer such as C. S. Lewis can write novels to promote a Christian worldview, and Philip Pullman can write novels in order to negate that view. A social critic like Christopher Hitchens can argue against belief using the vehicle of nonfiction, whereas a scientist like John Polkinghorne can use the same genre to make the case in favor of faith. In all these instances, however, the writers seem relatively certain of where they stand before they set pen to paper.

In contrast, when I speak of writing that ventures out "ahead of" its author, I am attempting to suggest that the author is writing without the security of definitive knowledge, without having answered all the questions in advance. Such an author has to allow for the possibility that these questions may be answered differently than she or he might have assumed. Such authors may express their own struggles with respect to religious belief, as Dostoevsky does in his letter of 1854, or as Nikos Kazantzakis does in his authorial preface to The Last Temptation of Christ. ${ }^{17}$ Taking this approach is particularly hazardous, since one's readers may tend to latch onto one particular aspect of one's oeuvre in which either faith or doubt seems to be in the

17 Nikos Kazantzakis, The Last Temptation of Christ, trans. P. A. Bien (New York: Touchstone, 1960). 
forefront, and to use that element alone to determine the author's attitudes toward faith. This helps to explain why readings of Dostoevsky veer so strongly in one direction or another-with some reading him as an atheist and others as a determined believer.

\section{Hazards historisch and geschichtlich}

In order to explore the differing hazards of writing "ahead of" or "behind" one's faith, I want to consider a different distinction entirely: the one offered by the German terms Historie and Geschichte. Both of these words have a very complex effective-history and therefore cannot be translated straightforwardly; for present purposes, however, let us describe them as "the things that happened" and "the story of the things that happened," respectively. The distinction is similar to that suggested by the Latin phrases res gestae ("the things that happened, the totality of events") and historia rerum gestarum ("the account of these events"). ${ }^{18}$ I think that this distinction might prove fruitful, not least because Nietzsche and Dostoevsky were both writing at a time when the difference between these two approaches (and the further differences they imply) was particularly vexed-and nowhere more intensely than in the theological context.

This was the era of what later came to be known as "Life of Jesus" research, which could be characterized as a shift in focus from Geschichte to Historie. Until the eighteenth century, and including both the Protestant and Catholic branches of the Western church, accounts of Jesus had traditionally been geschichtlich - focused on narrative and story, on the biblical texts as shaping a moral and imaginative world, rather than what we would today call a "historical" account. Enthusiasm for Geschichte was of course tempered by the work of Leopold von Ranke and everything that happened in his wake, as scholars in all fields found themselves called to set aside narrative and story and to focus on wie es eigentlich gewesen ist — "how things actually happened." ${ }^{19}$

18 For more on this distinction, particularly as it relates to a wide range of theological and political questions, see Michael Allen Gillespie, Hegel, Heidegger, and the Ground of History (Chicago: University of Chicago Press, 1984), 1-23.

19 Leopold von Ranke, Geschichte der lateinischen und germanischen Völker von 1494 bis 1514, 3rd ed. (Leipzig: Duncker und Humblot, 1884 [1824]), preface. 
In the theological context, this led to a particularly controversial shift, in which scholars began to ask, really for the first time (at least publicly), "What actually happened?" with respect to the Bible in general and the events surrounding the life of Jesus in particular. These writers-including Hermann Samuel Reimarus, David Friedrich Strauss, and Ernest Rénan, as well as many others-sought to shift this conversation ever more strongly in the direction of Historie. ${ }^{20}$ They were eager to reach back behind the accumulated layers of story and saga that, in their view, had blinded us to the true nature of Jesus. They wanted to bring him into the modern age as a truly historical figure: a human being who walked on the earth, did certain things, said certain things, and acted in a particular way. The picture of Jesus that emerged from this research was often strikingly different from the traditional version portrayed by the narratives of the Gospels. Researchers explained this by pointing out that the churches told stories about Jesus, whereas they were following von Ranke's advice of writing history only in terms of "what actually happened."

This, I want to suggest, may have been what Nietzsche was also seeking to do. We might even think of him as a Leben-Jesu-Forscher, following the path taken by a writer whose work he knew well: David Friedrich Strauss, of whom Nietzsche wrote in his Unzeitgemässe Betrachtungen. ${ }^{21}$ That text focuses not on Strauss's entry into the Life of Jesus research (Das Leben Jesu, kritisch bearbeitet of 1846) but rather on a much later text, Der alte und neue Glaube. Nevertheless, by the time of this later work, Strauss was even more radical in his rejection of traditional Christian claims about Jesus. Nietzsche is, of course, scathing in his critique of Strauss's work, for reasons to which I will return. I mention the connection here because it reinforces my students' perception that, although Nietzsche consistently expresses his rejection of Christian belief, he does not seem to be able to let it go. He returns time and again to theology, and to

20 The work of Reimarus was read only by a few close friends during his lifetime. It was published posthumously by Lessing as "Fragments from an Anonymous Writer" in Zur Geschichte und Literatur in 1774-78. Strauss's contribution was the most famous, perhaps: Das Leben Jesu, kritisch bearbeitet (Tubingen, 1846) was translated into English by George Eliot as The Life of Jesus, Critically Examined (London, 1846). Rénan wrote Vie de Jésus in 1863.

21 Friedrich Nietzsche, "David Strauss: The Confessor and the Author (1873)," in Untimely Meditations, trans. R. J. Hollingdale, with an introduction by J. P. Stern (Cambridge: Cambridge University Press, 1983), 3-55. 
theologians such as Strauss, only in order to repeat his claim that they really don't matter.

Because of Nietzsche's complete rejection of Christianity, however, he is not usually listed among the nineteenth-century "researchers into the life of Jesus." In putting him into this category, I am merely suggesting that he was undertaking some of the same kinds of work as those scholars who are more typically given this label. Like them, he was attempting to retrieve the specificity of the life and death of Jesus, and to rescue it from the religious thicket in which that life had been entangled-including the Jewish mind-set from which Jesus came and the Christian dogmatism into which he was absorbed. So we occasionally get Nietzschean asides in the form of mild appreciations for Jesus, including, famously, that "there was only one Christian, and he died on a cross." ${ }^{22}$ Of course, Nietzsche had no vested interest in rehabilitating the figure of Jesus per se; if, however, we were to expand slightly the definition of a "Life of Jesus researcher," we might recognize him as belonging to this way of thinking. He desired to reconstruct the Christian faith itself, using the same kind of methodological move as the Life of Jesus scholars, and working in their idiom. He wants us to know who Jesus really was, precisely to make it easier for us to dismiss him-and, more importantly, to dismiss everything that was built upon and around him. Like the Leben-Jesus-Forscher, he has settled his own score with that faith and now just wants "to give us the facts"in the partial hope that we, or at least some of the "higher men" among us, will strike out on a similar path.

Nietzsche's writing therefore lags "behind his faith" —or, rather, behind his unfaith - in the same way that Dostoevsky's writing ventures out ahead of his faith. Of course, writing "behind" one's religious views would seem to be the safer course, in that it follows the same pattern of other forms of Wissenschaft: first, determine the facts; then, describe them in writing. And lest this be thought of as a method only used by critics of religion, it should be observed that a number of theologians of the nineteenth and early twentieth centuries followed precisely the same path. The works of Friedrich Schleiermacher and Adolf Harnack provide us with prime examples of this approach; both were theologians who wanted to make sure that their scholarly work was placed on

22 Friedrich Nietzsche, The Antichrist, in The Portable Nietzsche, sec. 39, p. 612. 
the same footing as that of other disciplines, so they made certain to follow the same methodological pattern. ${ }^{23}$ But if we were to trace out the effective-history of their work, we would discover that for them, as for the Life of Jesus researchers, this kind of "serious scholarship about faith" has its own set of hazards. And those hazards may be particularly acute in the case of writing about the Christian faith.

\section{“Jesus Does Not Stay”}

To understand how this is so, we need to take a somewhat closer look at the methodological approach that I have described as "writing behind one's faith," and especially the form it took within Life of Jesus research. I want to focus on that movement's waning years - an era roughly contemporary with the period in which both Nietzsche and Dostoevsky stopped writing.

By the turn of the twentieth century, Life of Jesus research had developed a sufficiently robust status that accounts of its historical sojourn began to appear; it was a scholarly movement that had become, itself, the subject of scholarly investigation. The most thoroughgoing account of the movement is a book by Albert Schweitzer, the English title of which is The Quest of the Historical Jesus. His account demonstrates rather convincingly that, every time nineteenth-century historians sought to employ their best scholarly tools in order to discover "the real Jesus," what they actually discovered were portraits of themselves. In seeking to write a biography of this man in particular, they found themselves unwittingly writing their own autobiographies. To write a life of Jesus was to stare down into the murky depths of a well, straining to see the water at the bottom. As a face gradually appeared to form there, one imagined that one had finally gazed upon the face of Jesus; the face that one saw, of course, was nothing other than the reflection of one's own. As Schweitzer observes:

There is no historical task which so reveals a man's true self as the writing of a Life of Jesus. No vital force comes into the figure unless a man breathes into it all the hate or all the love of which he is capable. The stronger the love, or the stronger the hate, the more life-like is the figure which is produced. For

23 Adolf Harnack, What Is Christianity?, trans. Thomas Bailey Saunders, with an introduction by Rudolf Bultmann (New York: Harper and Row, 1957); Friedrich E. D. Schleiermacher, On Religion: Speeches to Its Cultured Despisers, trans. Rudolf Otto (New York: Harper and Row, 1958). 
hate as well as love can write a Life of Jesus, and the greatest of them are written with hate.... It was not so much hate of the Person of Jesus as of the supernatural nimbus with which it was so easy to surround Him, and with which He had in fact been surrounded.... And their hate sharpened their historical insight. ${ }^{24}$

Anyone who writes in depth about a particular historical figure must surely care about that figure, one way or another-be it through love or through hate. But in the case of Jesus, something else is at work. Here we have the founder of, or at least the chief figure in, one of the most significant moral and intellectual systems in the history of the world-a movement with ramifications in all directions (political, economic, artistic, cultural, sociological, psychological, and many more). It would be hard to find a historical figure more influential, or more polarizing, than Jesus of Nazareth. Few individuals have inspired more love (and hate) among those who have written about him.

Nietzsche was not writing as a historian in the traditional mode, but he was a superb genealogist. Thus, although his writing in a work like The Antichrist doesn't really resemble works like D. F. Strauss's Das Leben Jesu, kritisch bearbeitet, the latter work certainly did influence Nietzsche; in fact, he read it as a theology student in Bonn, and it was one of the books that led to his rejection of the Christian faith. ${ }^{25}$ Some commentators have speculated that one of the reasons for the virulence of Nietzsche's later attack on Strauss was that, particularly in Strauss's late work (Der alte und neue Glaube), he had come around to a more radical position on faith and religion - one not far, in fact, from that of Nietzsche himself. Nietzsche was always keen to distinguish himself from others who might have arrived at similar conclusions by another way. And thus, when Nietzsche eventually comes to write The Antichrist, he writes in a mode not so distant from that of the Leben Jesu genre (though in a more radical vein). As many have noted, it is a book in which Nietzsche actually puts himself forward as the proper alternative to Jesus; in this respect, he provides us with the most extreme case of Schweitzer's metaphor. Nietzsche, too, had looked down the well, and had seen the reflection of his own face.

24 Albert Schweitzer, The Quest of the Historical Jesus: A Critical Study of Its Progress from Reimarus to Wrede (London: SCM Press, 1954), 4.

25 Briefly recounted in J. P. Stern's introduction to Nietzsche, Untimely Meditations, xi. 
Thus, building on Schweitzer's claim about Life of Jesus researchersnamely, that "their hate sharpened their historical insight"-we can suggest that Nietzsche's hate sharpened his genealogical insight in a similar way. Yet Schweitzer can also help us understand why it might be the case that works like those of Strauss and Nietzsche-attempts to argue one's way out of faith, and to argue others out of it—are often not particularly persuasive. Admittedly, if one's faith were based purely on Historie, and if certain historical events were then called into question, one's faith might well be tested. But Christianity has never based its claims on Historie alone; indeed, until that category was invented in the modern era, few theologians would have suggested that believers should base their faith only on certain actual events that transpired in Palestine around the time of Tiberius Caesar. Most Christian belief is more interested in the Geschichte that developed later, in light of these events-including those writings later compiled as the New Testament but also including a huge range of stories, commentary, treatises, polemics, sermons, prayers, and meditations that were never officially canonized but that have had a tremendous influence nonetheless. If one's faith has been deeply formed over decades by such a wide range of material, then that faith seems unlikely to be easily deterred simply because one person has judged all this material to be worthless, and has written about that judgment in a post hoc fashion (having already determined the answers to all the relevant questions).

This returns us to my suggestion, made in passing much earlier in this chapter, that the hazards of this enterprise might best be characterized not as "writing about faith in a certain genre or with a certain method," but as writing about faith at all. Or perhaps it has to do with writing about a particular faith, about the Christian faith, and, in particular, about the God-man, Jesus Christ. ${ }^{26}$ This, at any rate, was Schweitzer's conclusion, who felt that any account of the life of Jesus was bound to fail —at least if it were written in the mode of Historie. In a famous passage (in the conclusion of his book), Schweitzer wrote,

The study of the Life of Jesus has followed a remarkable path. It set out in quest of the historical Jesus [um den historischen Jesus zu finden], believing that when it had found Him it could bring Him straight into our time as a Teacher and Saviour. It loosed the bands by which He had been riveted for

26 Particularly for its connections to Dostoevsky, an essential text is Vladimir Solovyev, Lectures on Godmanhood, ed. Peter P. Zouboff (International University Press, 1944). 
centuries to the stony rocks of ecclesiastical doctrine, and rejoiced to see life and movement coming into the figure once more, and the historical Jesus advancing, as it seemed, to meet it. But He does not stay [er blieb nicht stehen ]; He passes by our time and returns to His own. What surprised and dismayed the theology of the last forty years was that, despite all forced and arbitrary interpretations, it could not keep Him in our time, but had to let Him go. He returned to His own time, not owing to the application of any historical ingenuity, but by the same inevitable necessity by which the liberated pendulum returns to its original position. ${ }^{27}$

Er blieb nicht stehen: Jesus does not stay. The very absence of concrete historical data about him makes it impossible to turn him into a "modern man," impossible to treat him as one might treat any other great figure of Historie. He returns to his own time.

Some additional insight may be gained from a close look at the original German title of Schweitzer's book. The first part of the title is Von Reimarus zu Wrede; this signals that its account begins with the posthumously published reflections of Hermann Samuel Reimarus (who believed he was onto something so scandalous that he never even sought to publish it), and ends with the work of Wilhelm Wrede, who took the thoroughgoing skepticism that marked Life of Jesus research to its logical conclusion - that is, that not only was Jesus not the messiah, but he did not even claim to be. But it is the subtitle of Schweitzer's work that is particularly worthy of note: Eine Geschichte der Leben-Jesu-Forschung. Schweitzer self-consciously writes a Geschichte of Life of Jesus research, not a Historie - not "the things that actually happened," but an account of the things that happened (and indeed, his own account - which he admits is a very partial and interested one).

To understand the significance of Schweitzer's use of Geschichte in his title, it is important to remember that he had also been a participant in the movement known as Life of Jesus research. He had published his own "sketch" of the life of Jesus in the same year that Wrede's work appeared. ${ }^{28}$ That work has fallen into the same kind of obscurity as just about every other Historie that Schweitzer cites and reviews in his account of the movement. On the other hand, Schweitzer's account of that movement-his Geschichte-had quite the

27 Schweitzer, Quest, 397, translation slightly altered.

28 Albert Schweitzer, Das Messiantäts- und Leidensgeheimnis: Eine Skizze des Lebens Jesu (Tübingen: J. C. B. Mohr, 1901). 
opposite impact: it continues to be read widely, in many languages. It remains a significant and frequently cited text, not least for its observations about the mirror-imaging of inquiries into the life of Jesus - and for its haunting conclusion, which reminds us that "Jesus does not stay."

About a decade before Schweitzer's account appeared, another German theologian had summarized and criticized the Life of Jesus movement, and had proposed an alternative. This book, written by Martin Kähler, did not provide the kind of close reading and thoroughgoing account of the various Lives of Jesus, as Schweitzer did; instead, he challenged the movement at the methodological level. Kähler argued that no historian would accept the source materials that the scholars of the Life of Jesus school were using to create a biography of Jesus. This leads him to offer a quite remarkable claim: that the "real" Jesus is exactly one who is carried to us by the tradition-complete with all those historical accretions that so distressed those who embarked upon the Life of Jesus quest. Only by including all of this historical accumulation, says Kähler, can we really get a sense of who Jesus was for those who first encountered him - and, therefore, who he may be for us. In the case of Jesus, at least, we have no access to the res gestae; our truest portrait comes from a study of the historia rerum gestarum.

I have put off providing the title of Kähler's book, because it will take us back to my original claim as to how we might make use of the two German words for "history" as a means of helping us come to understand Dostoevsky's approach to faith. Kähler's title is Der sogenannte historische Jesus und der geschichtliche, biblische Christus. The English translation of this book, which was actually not available until 1964, provided a fairly literal rendering, employing the word historical for historisch and, for geschichtlich, the word historic - as in, an event of "historic" importance. ${ }^{29}$ The significance of Jesus is not so much as a historical figure, which is lost in the sands of time (though Kähler insisted that Christianity does not therefore forfeit its historical basis, for Jesus did really live and walk the earth). Still, the true relevance of Jesus is that he is a historic figure-one who has shaped the way that we tell our history (Geschichte). In this sense he is comparable to a figure like Socrates, about

29 Martin Kähler, The So-Called Historical Jesus and the Historic, Biblical Christ, with a foreword by Paul J. Tillich; trans., ed., and introduction by Carl E. Braaten (Philadelphia: Fortress Press, 1964). 
whom we know very little (and almost nothing that would be considered wholly reliable by a modern historian); yet, because of the testimony of others about his life and the traditions that bear him on, his impact on the history of the West is undeniable.

One can't write a Historie of Socrates or of Jesus; there is simply not enough historical information on which we can rely, not enough material to inform our scholarship at a level that would pass muster among professional historians. But we can write a Geschichte; we can offer an account. That is, in fact, what the Gospels are; moreover, it is also what Dostoevsky's novels are (though in a different sense). They are works that are partial and interested, focusing on Jesus not as a mere figure in a long line of historical figures or even "world-historical individuals," but as a phenomenon of "historic" importance-which is to say, important enough to deserve a Geschichte and not just a Historie.

\section{For or Against; Ahead or Behind; Historical or Historic}

Writing about Jesus (and about Christianity) will be more successful, and will have a deeper and more long-lasting impact on its readers, if authors allow their writing to venture out "ahead of their faith," as did Dostoevsky—not always knowing in advance how the story will end. This is hazardous, because one may always be misinterpreted as having "lost" one's faith or, at the very least, as having "settled" the questions (instead of merely disguising or subverting them). But this hazard can be offset somewhat by exploring the questions as broadly as possible, and by acknowledging that good arguments can be made for a variety of answers. This was, in fact, Dostoevsky's approach-and it has given his writings about faith a very long and interesting effective-history. His willingness to write "ahead of his faith" makes his work fascinating and relevant right up to the present day.

On the other hand, those who allow their writing to lag "behind their faith" seem very much a product of their particular age. This is not to say that Nietzsche's writings are not of interest or relevance today; obviously, the opposite is true. But his polemical writings against Christianity are more didactic, more prone to simple refutation, and therefore considerably less interesting than is his writing on other topics. To write "behind one's faith" is to operate with a different sort of hazard: such writing tends to generate an audience that has already come to the same conclusion as has the author. If those who read 
Nietzsche's diatribes against Christianity have not already reached the same conclusions, his arguments will tend to fall on deaf ears. And a similar fate awaits those who write in a similar mode, including the Life of Jesus researchers. If a reader were looking for a way of rejecting traditional Christian claims about Jesus, then these works would be welcomed; but then again, they would be unnecessary, because the reader would already have come to the same conclusion without the need for so much research and inquiry. Those who are less certain about rejecting Christianity often find themselves unconvinced by those who have already made a definitive decision in that regard. This helps us understand why the Life of Jesus researchers remain largely unread todayexcept when encountered through a Geschichte like Schweitzer's, which demonstrates just how much their work remains a child of its age.

At the conference at which this chapter was originally presented, flyers and programs were adorned with an image of Hans Holbein's Body of the Dead Christ in the Tomb. This painting, which hangs in the Basel Kunstmuseum, had a famously profound impact on Dostoevsky himself; he made use of it in one of his novels, and several conference participants made reference to it during the event. I had not previously considered the relationship between that painting and the issues that I raise in this chapter, but at the conference, it struck me as relevant in an interesting way. In particular, my reflections here may cast some light on Prince Myshkin's claim, in The Idiot, that the painting could lead one to lose one's faith. I certainly cannot explore this point in detail here, but I will mention it by way of conclusion - in the hope that others might take up the question in their own work.

Although he predated von Ranke by more than two centuries, Holbein worked at the very cusp of modernity. In his era, painters were beginning to strive toward a degree of realism that contrasted sharply with their medieval inheritance. In a sense, then, Holbein is painting Jesus in (what would later be described as) the mode of Historie, rather than that of Geschichte. This is, after all, precisely what a dead body would look like: there are no signs of divinity or holiness, and Christ's face is the very opposite of peaceful rest. Consider this painting in contrast to religious art created in a geschichtlich mode: such work is more concerned about the story (and thus also about the resurrection that would come) than it is about the details of documentary history. Western medieval painting bears this mark, as does Eastern Orthodox iconography. 
As with visual imagery, so also with narrative accounts. Those that focus on the res gestae, the things that actually happened, will generate writing that lags behind the faith of its creator, a merely documentary depiction of the way things are. In contrast, those that focus on the historia rerum gestarum-the narrative account of the things that happened, the Geschichte-will encourage writing that advances ahead of the artist's or the author's faith. Such creative works keep the questions open and generate the kind of polyphonic depth for which Dostoevsky's fiction is rightly celebrated. The Christ that Dostoevsky professed he would hold onto, even against the truth, was not Holbein's dead body - not the historical figure of Jesus, about whose corpse definitive historical and scientific judgments could be made (and in fact had already been made). Rather, Dostoevsky's Christ was much closer to the figure that adorns Orthodox iconography: deeply embedded in the narratives of his life and his relationship to God. This Christ is a phenomenon, not of historical, but of historic significance. 
